\title{
Pengaruh Kompensasi, Lingkungan Kerja dan Motivasi Terhadap Kepuasan Kerja Guru pada SMA Swasta Perkumpulan Amal Bakti 4 Sampali Medan
}

\author{
Mhd. Andi Rasyid \\ Hasrudy Tanjung
}

Program Studi Magister Manajemen, Universitas Muhammadiyah Sumatera Utara Medan, Indonesia Jl. Denai No. 217, Tegal Sari Mandala II, Medan Denai, Kota Medan, Sumatera Utara 20371

Email andirasyid.se91@gmail.com

\begin{abstract}
Abstrak. Kepuasan kerja guru menjadi salah satu faktor yang harus diperhatikan, apabila guru merasakan kepuasan dalam dalam bekerja, maka akan tercipta semangat kerja yang tinggi sehingga tujuan sekolah dapat tercapai secara maksimal. Banyak usaha yang telah dilaksanakan untuk meningkatkan kepuasan kerja guru. Diantaranya adalah dengan memberikan kompensasi yang sesuai, melengkapi dan menyiapkan berbagai sarana dan prasarana yang diperlukan guru dalam mengajar, memberikan motivasi kepada guru dan lain sebagainya. Namun, usaha yang sudah dilaksanakan tampaknya belum memperlihatkan hasil yang memuaskan. Tujuan dari penelitian ini adalah untuk mengetahui pengaruh kompensasi, lingkungan kerja dan motivasi terhadap kepuasan kerja guru pada SMA Swasta Perkumpulan Amal Bakti 4 Sampali Medan. Penelitian ini menggunakan pendekatan asosiatif, yaitu penelitian yang dilakukan untuk mengetahui pengaruh atau hubungan antara variabel bebas dengan variabel terikat. Hasil penelitian menunjukkan bahwa secara parsial kompensasi memiliki pengaruh yang signifikan terhadap kepuasan kerja. Secara parsial lingkungan kerja memiliki pengaruh yang tidak signifikan terhadap kepuasan kerja. Secara parsial motivasi memiliki pengaruh yang signifikan terhadap kepuasan kerja. Secara simultan kompensasi, lingkungan kerja dan motivasi memiliki pengaruh yang signifikan terhadap kepuasan kerja.
\end{abstract}

Kata Kunci : Kompensasi, Lingkungan Kerja, Motivasi dan Kepuasan Kerja

\begin{abstract}
Teacher job satisfaction becomes one of the factors that must be considered, if teachers feel satisfaction in working, there will be a high morale so that the school's goals can be achieved optimally. Many attempts have been made to improve teacher job satisfaction. Among them is by providing appropriate compensation, completing and preparing various facilities and infrastructure needed by teachers in teaching, providing motivation to teachers and so forth. However, the efforts that have been carried out do not seem to show satisfactory results. The purpose of this study was to determine the effect of compensation, work environment and motivation on teacher job satisfaction in the Private High Schools of the Bakali Charity Association 4 Sampali Medan. This study uses an associative approach, namely research conducted to determine the effect or relationship between the independent variables with the dependent variable. The results showed that partial compensation had a significant effect on job satisfaction. Partially the work environment has no significant effect on job satisfaction. Partially motivation has a significant effect on job satisfaction. Simultaneously compensation, work environment and motivation have a significant effect on job satisfaction.
\end{abstract}

Keywords : Compensation, Work Environment, Motivation and Job Satisfaction

\section{PENDAHULUAN}

Dalam mengelola suatu sekolah, guru merupakan aset yang sangat penting karena tanpa adanya guru, sekolah akan sulit untuk mencapai tujuan pendidikan. Sebaik apapun kurikulum yang diterapkan dalam dunia pendidikan, guru tetap berperan sangat besar untuk mencapai tujuan dari kurikulum tersebut. Peran guru sangat penting dan tidak dapat dibedakan antara guru yang telah bersertifikat dengan guru yang belum bersertifikat, keduanya 
tetap harus bekerja secara profesional. Undang-Undang Nomor 14 Tahun 2005 tentang guru dan dosen Pasal 1 ayat 1 mendefinisikan bahwa guru adalah pendidik profesional dengan tugas utama mendidik, mengajar membimbing, mengarahkan, melatih, menilai dan mengevaluasi peserta didik pada pendidikan anak usia dini, jalur pendidikan formal, pendidikan dasar dan pendidikan menengah.

Kepuasan kerja merupakan hasil dari berbagai macam sikap yang terkait dengan pekerjaan dan faktor-faktor khusus seperti upah, kestabilan pekerjaan, ketentraman kerja, kesempatan untuk maju, penilaian kerja yang adil, hubungan sosial di dalam pekerjaan. Kepuasan kerja adalah keadaan emosi yang positif atau baik dari hasil pengalaman kerja seseorang (Handoko, 2013).

Kepuasan kerja dapat menjadi faktor pendorong meningkatnya kinerja guru yang pada gilirannya akan memberikan kontribusi kepada peningkatan kinerja di sekolah. Sekolah akan mendapat timbal balik dalam bentuk keuntungan jika kinerja guru meningkat dengan adanya kepuasan kerja. Kepuasan kerja guru dapat menimbulkan perasaan yang menyenangkan atau tidak menyenangkan dalam bekerja sehingga dapat mempengaruhi kinerja guru. Kepuasan kerja guru menjadi salah satu faktor yang harus diperhatikan, apabila guru merasakan kepuasan dalam dalam bekerja, maka akan tercipta suasana yang penuh kebersamaan, memiliki tanggung jawab yang sama, iklim komunikasi yang baik dan juga semangat kerja yang tinggi sehingga tujuan sekolah dapat tercapai secara maksimal. Tetapi sebaliknya apabila guru tidak merasa puas, maka akan tercipta suasana yang kaku, membosankan, dan semangat tim yang rendah. Banyak usaha yang telah dilaksanakan untuk meningkatkan kepuasan kerja guru. Diantaranya adalah dengan melengkapi dan menyiapkan berbagai sarana dan prasarana yang diperlukan guru dalam mengajar, memberikan kesempatan untuk melanjutkan pendidikan, pelatihan dan penataran, dan lain sebagainya. Namun, usaha yang sudah dilaksanakan tampaknya belum memperlihatkan hasil yang memuaskan.

Kompensasi juga merupakan faktor peningkatan kinerja (Khair, 2017). Kompensasi meliputi imbalan finansial dan jasa nirwujud serta tunjangan yang diterima oleh para karyawan sebagai bagian dari hubungan kepegawaian (Bismala, Arianty, \& Farida, 2017). Oleh karena itu perhatian organisasi terhadap pengaturan kompensasi secara rasional dan adil sangat diperlukan. Bila guru memandang pemberian kompensasi tidak memadai prestasi kerja, motivasi maupun kepuasan kerja mereka cenderung akan menurun. Kompensasi itu sendiri dapat dibagi menjadi dua yaitu kompensasi langsung dan tak langsung. Kompensasi langsung merupakan imbalan jasa kepada pegawai yang diterima secara langsung, rutin atau periodik karena yang bersangkutan telah memberikan bantuan/sumbangan untuk mencapai tujuan organisasi, dan kompensasi langsung meliputi gaji, bonus/insentif, komisi. Kompensasi langsung biasanya berpengaruh terhdap kepuasan kerja. Selain kompensasi langsung, kompensasi tak langsung juga mempunyai peranan yang tak kalah pentingnya untuk meningkatkan kinerja karyawan. Dan kompensasi tak langsung meliputi tunjangan hari raya dan tunjangan kesehatan (Parmin, 2017).

Faktor lain yang mempengaruhi kepuasan kerja pegawai/guru dalam melaksanakan tugas adalah lingkungan kerja yaitu segala sesuatu yang ada di sekitar pekerja, yang dapat mempengaruhi dirinya dalam menjalankan tugas. Lingkungan kerja yang nyaman dan aman akan membuat guru juga ikut merasa nyaman bekerja sehingga tugas yang dilakukan oleh para guru juga dapat dilaksanakan dengan baik dan itu mempengaruhi kepuasan bekerja guru.

Banyak faktor yang mempengaruhi keberhasilan disekolah dalam mencapai tujuan pendidikan. Salah satunya adalah guru, karena berkaitan langsung dengan kegiatan pembelajaran di sekolah. Dalam hal ini guru diharapkan dapat memberikan hasil yang maksimal sehingga tujuan pendidikan disekolah dapat tercapai. Oleh karena itu untuk 
mendukung agar tujuan pendidikan di sekolah berhasil secara maksimal, maka perlu diperhatikan mengenai kepuasan kerja guru. Kepuasan kerja merupakan merupakan salah satu komponen dari kepuasan hidup, sehingga menjadi hal yang sangat penting untuk diperhatikan dalam pengembangan karir guru. Bila guru tidak mendapatkan kepuasan dari pekerjaannya, maka motivasi mereka dapat menurun, absensi dan keterlambatan meningkat dan menjadi semakin sulit untuk bekerja sama atau untuk mengadakan suatu perubahan. Hal ini menunjukkan bahwa kepuasan kerja guru akan ikut menjadi penentu terhadap keberhasilan sekolah dalam mewujudkan tujuan pendidikan. Kepuasan kerja sangat berpengaruh bagi kelangsungan kegiatan organisasi disekolah.

Motivasi kerja yang ditunjukkan dengan dukungan aktivitas yang mengarah pada tujuan (Daulay, Khair, Putri, \& Astuti, 2017). Motivasi dari dalam seorang pegawai/guru dapat berasal dari kebutuhan akan uang, penghargaan, kekuasaan, dan pengakuan. Motivasi dari luar dapat berasal dari keluarga, teman kerja maupun atasan (Arianty, Bahagia, Lubis, \& Siswadi, 2016). Motivasi ada dua jenis, yaitu motivasi positif dan motivasi negatif. Motivasi positif adalah proses mempengaruhi orang dengan memberikan kemungkinan mendapatkan hadiah sementara motivasi negatif adalah proses mempengaruhi seseorang melalui kekuatan ketakutan seperti kehilangan pengakuan, uang atau jabatan. Motivasi ada dua bentuk yaitu motivasi intrinsik dan motivasi ekstrinsik. Motivasi intrinsik adalah pendorong kerja yang bersumber dari dalam diri pekerja berupa kesadaran tentang makna pekerjaan yang dilaksanakan. Motivasi ekstrinsik adalah pendorong kerja yang bersumber dari luar diri pekerja berupa suatu kondisi yang mengharuskan melaksanakan pekerjaan secara maksimal.

Berdasarkan hasil riset awal di SMA Swasta Perkumpulan Amal Bakti atau disingkat PAB 4 Sampali Medan dapat dilihat bahwa kepuasan kerja yang diberikan kepada guru rendah. Kepuasan kerja yang dimaksud menjadi penting untuk dibahas dibicarakan disini dalam dunia pendidikan karena kepuasan kerja akan mempengaruhi kinerja guru, produktivitas lembaga dan hasil belajar siswa. Buruknya kinerja sebagian guru di lembaga ini diduga akibat dari rendahnya kepuasan kerja dari guru-guru tersebut. Sedangkan rendahnya kepuasan kerja itu sendiri merupakan akibat dari kurangnya penghargaan terhadap guru dari pihak sekolah, lingkungan sekolah yang kurang nyaman dan rendahnya motivasi mengakibatkan guru berprestasi kurang di lembaga pendidikan SMA Swasta PAB 4 Sampali Medan. Selain itu ternyata juga ditemukan permasalahan yang dapat mempengaruhi kepuasan kerja guru di SMA Swasta PAB 4 Sampali Medan yaitu permasalahan kompensasi, kompensasi yang diberikan tergantung oleh kemampuan pihak yayasan. Jika kemampuan yayasan baik maka kompensasi baik begitu sebaliknya. Lingkungan kerja yang terdapat di SMA Swasta PAB 4 Sampali Medan juga kurang nyaman bagi para guru, jauhnya lokasi sekolah dari perkotaan membuat guru harus menggunakan kendaraan pribadi. Serta terdapat masalah motivasi, menurunnya motivasi kerja guru dikarenakan kurangnya perhargaan dari pihak sekolah terhadap guru berprestasi sehingga guru kurang termotivasi dalam melaksanakan pekerjaannya.

\section{LANDASAN TEORI}

\section{Kepuasan Kerja}

Kepuasan kerja adalah sikap umum terhadap pekerjaan seseorang, yang menunjukkan perbedaan antara jumlah penghargaan yang diterima pekerja dan jumlah yang mereka yakini seharusnya mereka terima (Robbins, 2012). Kepuasan kerja merupakan sikap (positif) tenaga kerja terhadap pekerjaannya, yang timbul berdasarkan penelitian terhadap situasi kerja. Penilaian tersebut dapat dilakukan terhadap salah satu pekerjaannya. Penilaian dilakukan sebagai rasa menghargai dalam mencapai salah satu nilai-nilai penting dalam pekerjaan. 
Karyawan yang puas lebih menyukai situasi kerjanya daripada karyawan yang tidak puas, yang tidak menyukainya situasi kerjanya (Hamali, 2016).

Menurut Handoko, (2011), kepuasan kerja adalah keadaan emosional yang menyenangkan atau tidak menyenangkan bagi para karyawan memandang pekerjaan mereka. Kepuasan kerja mencerminkan perasaan seseorang terhadap pekerjaannya. Ini tampak dalam sikap positif karyawan terhadap pekerjaan dan segala sesuatu yang dihadapi dilingkungan kerjanya. Ada dua faktor yang memengaruhi kepuasan kerja menurut (Mangkunegara, 2016), yaitu faktor Karyawan, yaitu kecerdasan (IQ), kecakapan khusus, umur, jenis kelamin, kondisi fisik, pendidikan, pengalaman kerja, masa kerja, kepribadian, emosi, cara berfikir, persepsi dan sikap kerja. 2) Faktor Pekerjaan, yaitu jenis pekerjaan, struktur organisasi, pangkat (golongan), kedudukan, mutu pengawasan, jaminan finansial, kesempatan promosi jabatan, interaksi sosial, dan hubungan kerja.

Untuk melihat apakah kepuasan kerja memang sudah dirasakan guru disekolah, dibawah ini dijelaskan indikator kepuasan kerja. Menurut Robbins, (2012) ada dua pendekatan yang sering dipakai untuk mengukur tingkat kepuasan kerja seseorang yaitu : 1) Pendekatan nilai global tunggal (single global rating). Pendekatan nilai global tunggal (single global rating) tidak lebih dari meminta individu-individu untuk menjawab satu pertanyaan, yaitu menanyakan sebuah pertanyaan kepada individu yang ingin diukur kepuasannya. 2) Pendekatan skor penjumlahan (summation score). Pendekatan skor penjumlahan (summation score) mengenali elemen-elemen utama dalam suatu pekerjaan dan menanyakan perasaan karyawan mengenai masing-masing elemen.

\section{Kompensasi}

Besarnya balas jasa telah ditentukan dan diketahui sebelumnya, sehingga karyawan secara pasti mengetahui besarnya balas jasa/kompensasi yang akan diterimanya. Kompensasi inilah yang akan dipergunakan karyawan itu beserta keluarganya untuk memenuhi kebuthan-kebutuhannya (Khair, 2017). Besarnya kompensasi mencerminkan status, pengakuan, dan tingkat pemenuhan kebutuhan yang dinikmati oleh karyawan bersama keluarganya. Jika balas jasa yang diterima karyawan semakin besar berarti jabatannya semakin tinggi, statusnya semakin baik, dan pemenuhan kebutuhan yang dinikmatinya semakin banyak pula. Dengan demikian, kepuasan kerjanya juga semakin baik. Disinilah letak pentingnya kompensasi bagi karyawan sebagai seorang penjual tenaga (fisik dan fikiran).

Menurut Hasibuan, (2018) Kompensasi adalah semua pendapatan yang berbentuk uang, barang langsung atau tidak langsung yang diterima karyawan sebagai imbalan atas jasa yang diberikan kepada perusahaan. Sedangkan menurut (Panggabean, 2004), kompensasi adalah semua jenis penghargaan yang berupa uang atau bukan uang yang diberikan kepada pegawai secara layak dan adil atas jasa mereka dalam mencapai tujuan organisasi.

Kompensasi merupakan kontra prestasi terhadap penggunaan tenaga atau jasa yang telah diberikan oleh tenaga kerja. Kompensasi merupakan jumlah paket yang ditawarkan organisasi kepada pekerja sebagai imbalan atas penggunaan tenaga kerjanya (Wibowo, 2015). Banyak faktor yang dapat mempengaruhi besar kecilnya tingkat kompensasi. Hal ini perlu mendapat perhatian supaya prinsip pengupahan adil dan layak lebih baik dan kepuasan kerja dapat tercapai. Faktor-faktor yang mempengaruhi kompensasi menurut (Mangkunegara, 2016) yaitu : 1) Faktor Pemerintah. 2) Penawaran bersama antara perusahaan dan pegawai. 3) Standar dan biaya hidup pegawai yaitu. 4) Ukuran perbandingan upah. 5) Permintaan dan persediaan. 6) Kemampuan membayar. Menurut Flippo dalam Handoko (2011), kompensasi dibagi menjadi : 1) Kompensasi Langsung (Direct Compensation) meliputi a) Gaji, b) Upah, c) Insentif, d) Bonus. 2) Kompensasi tidak langsung (Indirect Compensation) dalam bentuk : a) Istirahat 
on-the-job, b) Hari-hari sakit, c) Liburan dan cuti, d) Alasan-alasan lain kehamilan, kecelakaan, dan lain-lain.

\section{Lingkungan Kerja}

Lingkungan kerja adalah tempat di mana pegawai melakukan aktivitas setiap harinya. Lingkungan kerja yang kondusif memberikan rasa aman dan memungkinkan pegawai untuk dapat bekerja optimal (Khair, Bismala, Arianty, \& Pratami, 2016). Lingkungan kerja dapat mempengaruhi emosional karyawan. Jika karyawan menyenangi lingkungan kerja di mana dia bekerja, maka karyawan tersebut akan betah di tempat kerjanya, melakukan aktivitasnya sehingga waktu kerja dipergunakan secara efektif. Suatu kondisi lingkungan kerja dikatakan baik atau sesuai apabila manusia dapat melaksanakan kegiatan secara optimal, sehat, aman dan nyaman. Kesesuaian lingkungan kerja dapat dilihat akibatnya dalam jangka waktu yang lama. Lebih jauh lagi lingkungan-lingkungan kerja yang kurang baik dapat menuntut tenaga kerja dan waktu yang lebih banyak dan tidak mendukung diperolehnya rencangan sistem kerja yang efisien.

Kondisi lingkungan kerja sangat berpengaruh terhadap kepuasan kerja pegawai. Lingkungan kerja merupakan suatu lingkungan dimana para pegawai bekerja dan dapat mempengaruhi mereka dalam menjalankan tugas-tugas yang dibebankan. (Sedarmayanti, 2017) menyatakan bahwa Lingkungan kerja adalah keseluruhan alat perkakas dan bahan yang dihadapi, lingkungan sekitarnya di mana seseorang bekerja, metode kerjanya, serta pengaturan kerjanya baik sebagai perseorangan maupun sebagai kelompok.

Menurut Nitisemito, (2011) mendefinisikan lingkungan kerja sebagai segala sesuatu yang ada di sekitar para pekerja yang dapat mempengaruhi dirinya dalam menjalankan tugas tugas yang diembankan. Sementara itu menurut Schultz dalam (Mangkunegara, 2014) mengemukakan bahwa Lingkungan atau kondisi kerja adalah semua aspek fisik kerja psikologis kerja dan peraturan kerja yang dapat mempengaruhi kepuasan kerja dan pencapaian produktivitas kerja. Faktor yang mempengaruhi lingkungan kerja fisik menurut (Sedarmayanti, 2017) adalah : 1) Penerangan/pencahayaan di tempat kerja, 2) Temperatur di tempat kerja, 3) Kelembaban di tempat kerja, 4) Sirkulasi udara di tempat kerja, 5) Kebisingan di tempat kerja, 6) Getaran mekanis di tempat kerja, 7) Bau-bauan di tempat kerja, 8) Tata warna di tempat kerja, 9) Dekorasi di tempat kerja, 10) Musik di tempat kerja, 11) Keamanan di tempat kerja. Dalam mengukur variabel lingkungan kerja terdapat beberapa indikator, penelitian ini dimensi dan indikator mengadaptasi menurut (Sedarmayanti, 2017) yaitu : 1) Lingkungan kerja fisik, dengan indikator sebagai berikut : a) Penerangan, b) Sirkulasi udara, c) Kebisingan, d) Fasilitas, e) Warna. Adapun indikator lingkungan kerja non fisik mengadaptasi menurut (Soetjipto, 2010) sebagai berikut : a) Hubungan yang harmonis, b) Kesempatan untuk maju, c) Keamanan dalam pekerjaan.

\section{Motivasi Kerja}

Motivasi kerja yang baik akan membuat kualitas kerja karyawan dan mampu mempengaruhi orang lain. Menurut Bangun, (2018), motivasi adalah suatu tindakan untuk mempengaruhi orang lain agar berperilaku (to behave) secara teratur. Menurut (Manullang, 2012), motivasi adalah suatu kekuatan dari dalam atau luar diri manusia untuk mendorong semangat untuk mengejar sesuatu keinginan dan tujuan tertentu. Sutrisno, (2014) menyatakan bahwa Motivasi adalah suatu faktor yang mendorong seseorang untuk melakukan suatu aktivitas tertentu, oleh karena itu motivasi sering kali diartikan pula sebagai faktor pendorong perilaku seseorang. Setiap aktivitas yang dilakukan oleh seseorang pasti memiliki suatu faktor yang mendorong aktivitas tersebut. Wibowo, (2015) menyatakan bahwa Motivasi merupakan 
dorongan untuk bertindak terhadap serangkaian proses perilaku manusia dengan mempertimbangkan arah, intensitas, dan ketekunan pada pencapaian tujuan. Sedangkan elemen yang terkandung dalam motivasi meliputi unsur membangkitkan, mengarahkan, menjaga, menunjukkan intensitas, bersifat terus-menerus dan adanya tujuan.

Hamali, (2016) menyatakan bahwa Motivasi adalah proses mempengaruhi atau mendorong dari luar terhadap seseorang atau kelompok kerja agar mereka mau melaksanakan sesuatu yang telah ditetapkan. Motivasi atau dorongan dimaksudkan sebagai desakan yang alami untuk memuaskan dan mempertahankan kehidupan. Menurut Sutrisno, (2014) menyatakan faktor-faktor motivasi dibedakan atas faktor intern dan faktor ekstern yang berasal dari karyawan. Adapun penjelasan dari kedua faktor yang mempengaruhi motivasi adalah : 1) Faktor Intern, antara lain : a) Keinginan untuk dapat hidup , b) Keinginan untuk dapat memiliki, c) Keinginan untuk memperoleh penghargaan, d) Keinginan untuk memperoleh pengakuan. 2) Faktor Ekstern antara lain : a) Kondisi lingkungan kerja, b) Kompensasi yang memadai, c) Supervisi yang baik, d) Adanya jaminan kerja, e) Status dan tanggung jawab, f) Peraturan yang fleksibel. Dengan mengukur motivasi kerja maka perusahaan dapat melihat tingkat motivasi yang dibutuhkan organisasi jika tidak sesuai maka tugas organisasi adalah meningkatkan motivasi pegawai. Adapun indikator mengenai motivasi menurut Mangkunegara, (2017) adalah 1) kerja keras, 2) orientasi masa depan, 3) tingkat cita-cita yang tinggi, 4) orientasi tugas dan keseriusan tugas, 5) usaha untuk maju, 6) ketekunan bekerja, 7) hubungan dengan rekan kerja, dan 8) pemanfaatan waktu.

\section{Kerangka Konseptual}

\section{Pengaruh Kompensasi Terhadap Kepuasan Kerja}

Kompensasi sangat penting bagi pegawai, hal ini karena kompensasi merupakan sumber penghasilan bagi pegawai dan keluarganya. Kompensasi juga merupakan gambaran dalam status sosial bagi pegawai. Tingkat penghasilan sangat berpengaruh dalam menentukan standar kehidupan. Kompensasi yang diberikan kepada pegawai sangat berpengaruh pada tingkat kepuasan kerja dan motivasi kerja, serta hasil kerja. Perusahaan yang menentukan tingkat upah dengan mempertimbangkan standar kehidupan normal, akan memungkinkan pegawai bekerja dengan penuh motivasi. Hal ini karena motivasi kerja pegawai banyak dipengaruhi oleh terpenuhi tidaknya kebutuhan minimal kehidupan pegawai dan keluarganya, (Hamali, 2016). Hasil penelitian (Jufrizen, 2015); (Hidayati \& Saputra, 2018); (Mahendrawan \& Indrawati, 2015); (Jufrizen, 2016); ( Handoko \& Rambe, 2018) dan (Parmin, 2017) menyimpulkan bahwa adanya pengaruh positif dan signifikan antara kompensasi terhadap kinerja dengan kepuasan kerja sebagai variabel intervening.

\section{Pengaruh Lingkungan Kerja terhadap Kepuasan Kerja}

Kondisi lingkungan kerja sangat berpengaruh terhadap kepuasan kerja pegawai. Lingkungan kerja merupakan suatu lingkungan dimana para pegawai bekerja dan dapat mempengaruhi mereka dalam menjalankan tugas-tugas yang dibebankan. Lingkungan kerja merupakan keseluruhan alat perkakas dan bahan yang dihadapi, lingkungan sekitarnya di mana seseorang bekerja, metode kerjanya, serta pengaturan kerjanya baik sebagai perseorangan maupun sebagai kelompok, (Sedarmayanti, 2017). Lingkungan kerja sebagai segala sesuatu yang ada di sekitar para pekerja yang dapat mempengaruhi dirinya dalam menjalankan tugas tugas yang diembankan, (Nitisemito, 2011). Hasil penelitian (Nabawi, 2019); (Tamali \& Munasip, 2019); (Astuti \& Iverizkinawati, 2018) menyimpulkan bahwa terdapat pengaruh antara lingkungan kerja terhadap kepuasan kerja. 


\section{Pengaruh Motivasi Terhadap Kepuasan Kerja}

Motivasi adalah suatu faktor yang mendorong seseorang untuk melakukan suatu aktivitas tertentu, oleh karena itu motivasi sering kali diartikan pula sebagai faktor pendorong perilaku seseorang. Kepuasan kerja adalah perasaan perasaan yang menyokong atau tidak menyokong dalam diri pegawai dalam bekerja.

Berhasil atau tidaknya suatu organisasi sebagian besar ditentukan oleh pemimpin dalam meningkatkan prestasi kerja para bawahannya. Motivasi seseorang melakukan suatu pekerjaan karena adanya suatu kebutuhan hidup yang harus dipenuhi. Kebutuhan ini dapat berupa kebutuhan ekonomis dan kebutuhan non ekonomi. Dengan segala kebutuhan tersebut, seseorang dituntut untuk lebih giat dan aktif dalam bekerja untuk mencapai hal ini diperlukan adanya motivasi dalam melakukan pekerjaan, oleh karena itu jika pegawai yang mempunyai motivasi kerja yang tinggi biasanya mempunyai kinerja yang tinggi pula (Agustini, 2011). Berdasarkan hasil penelitian (Gijoh, 2013); (Siahaan, Salim, \& Siahaan, 2014); (Kartika \& Kaihatu, 2010); (Dolphina, 2012) menyimpulkan bahwa motivasi berpengaruh positif dan signifikan terhadap kepuasan kerja.

\section{Pengaruh Kompensasi, Lingkungan Kerja dan Motivasi Kerja terhadap Kepuasan Kerja}

Besarnya balas jasa telah ditentukan dan diketahui sebelumnya, sehingga karyawan secara pasti mengetahui besarnya balas jasa/kompensasi yang akan diterimanya. Kompensasi inilah yang akan dipergunakan karyawan itu beserta keluarganya untuk memenuhi kebuthan-kebutuhannya. Besarnya kompensasi mencerminkan status, pengakuan, dan tingkat pemenuhan kebutuhan yang dinikmati oleh karyawan bersama keluarganya. Jika balas jasa yang diterima karyawan semakin besar berarti jabatannya semakin tinggi, statusnya semakin baik, dan pemenuhan kebutuhan yang dinikmatinya semakin banyak pula. Dengan demikian, kepuasan kerjanya juga semakin baik. Disinilah letak pentingnya kompensasi bagi karyawan sebagai seorang penjual tenaga (fisik dan fikiran).

Suatu kondisi lingkungan kerja dikatakan baik atau sesuai apabila manusia dapat melaksanakan kegiatan secara optimal, sehat, aman dan nyaman. Kesesuaian lingkungan kerja dapat dilihat akibatnya dalam jangka waktu yang lama. Lebih jauh lagi lingkungan-lingkungan kerja yang kurang baik dapat menuntut tenaga kerja dan waktu yang lebih banyak dan tidak mendukung diperolehnya rencangan sistem kerja yang efisien. Kondisi lingkungan kerja sangat berpengaruh terhadap kepuasan kerja pegawai. Lingkungan kerja merupakan suatu lingkungan dimana para pegawai bekerja dan dapat mempengaruhi mereka dalam menjalankan tugas-tugas yang dibebankan.

Motivasi merupakan dorongan untuk bertindak terhadap serangkaian proses perilaku manusia dengan mempertimbangkan arah, intensitas, dan ketekunan pada pencapaian tujuan. Sedangkan elemen yang terkandung dalam motivasi meliputi unsur membangkitkan, mengarahkan, menjaga, menunjukkan intensitas, bersifat terus-menerus dan adanya tujuan. Motivasi adalah proses mempengaruhi atau mendorong dari luar terhadap seseorang atau kelompok kerja agar mereka mau melaksanakan sesuatu yang telah ditetapkan. Motivasi atau dorongan dimaksudkan sebagai desakan yang alami untuk memuaskan dan mempertahankan kehidupan. Hasil penelitian (Husni, Musnadi, \& Faisal, 2018) yang menyimpulkan bahwa hasil penelitian antara variabel lingkungan kerja, kompensasi dan motivasi mempunyai pengaruh yang positif dan signifikan secara simultan terhadap kepuasan kerja. 


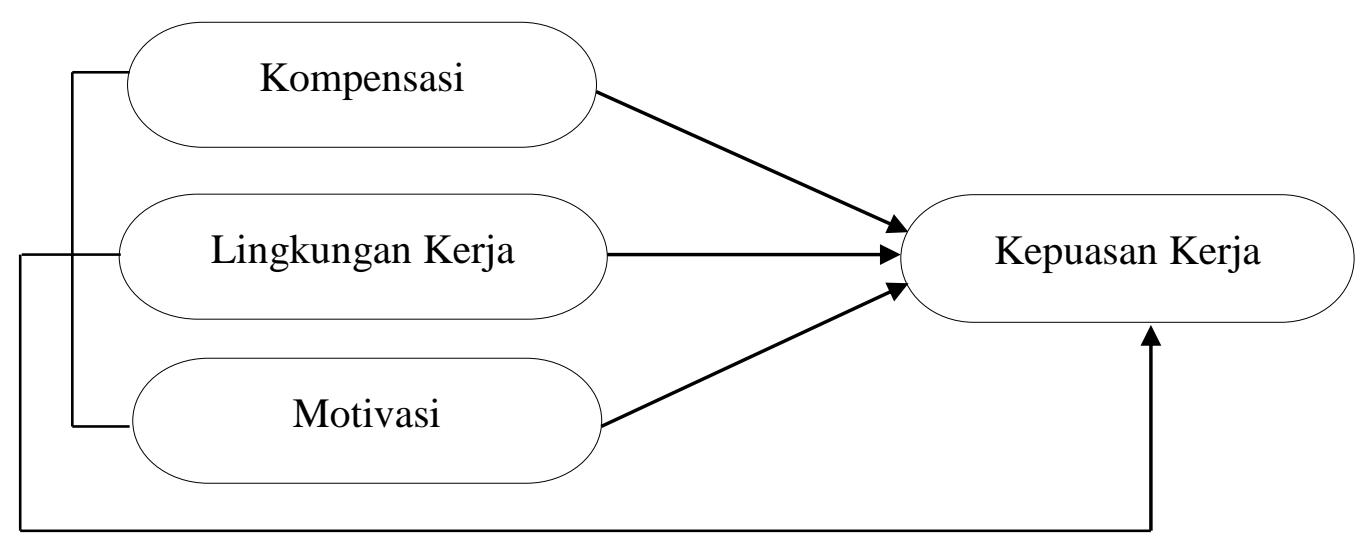

\section{Gambar 1. Paradigma Penelitian}

\section{METODE PENELITIAN}

Pendekatan dalam penelitian ini adalah dengan menggunakan pendekatan asosiatif, pendekatan asosiatif adalah pendekatan dimana untuk mengetahui bahwa adanya hubungan atau pengaruh diantara kedua variabel (variabel bebas dan variabel terikat). Teknik pengumpulan data yang digunakan adalah menggunakan daftar pernyataan (angket). Populasi penelitian ini adalah seluruh guru tetap pada SMA Swasta PAB 4 Sampali Medan yang berjumlah 30 orang. Pada penelitian ini, dikarenakan jumlah populasi sedikit maka sampel pada penelitian ini menggunakan keseluruhan populasi yang ada yaitu 30 orang guru menggunakan sampling jenuh. Menurut Sugiyono, (2017) sampling jenuh yaitu teknik penetuan sampel bila semua anggota populasi digunakan sebagai sampel. Pengolahan data menggunakan perangkat lunak SPSS versi 2.1, dengan pengujian instrument, pengujian asumsi klasik, dan teknik analisi data menggunakan analisis regresi linier berganda.

\section{HASIL DAN PEMBAHASAN PENELITIAN Hasil Penelitian}

Uji normalitas bertujuan untuk menguji apakah apakah dalam metode regresi, variabel terikat dan variabel bebas keduanya mempunyai distribusi normal atau tidak. Model regresi yang baik adalah data yang berdistribusi normal atau mendekati normal.Berikut adalah hasil pengujian normalitasdapat dilihat dari grafik probability plot, hasil penelitian data yang telah diolah dengan pengujian SPSS versi 21.0 adalah sebagai berikut:

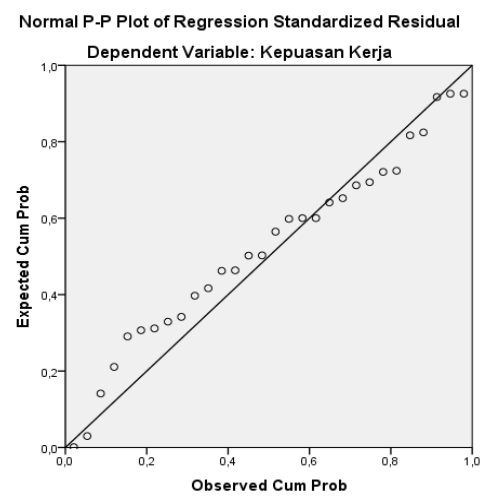

Gambar 2. Hasil Pengujian Normalitas

Pada gambar diatas diketahui hasil dari pengujian normalitas bahwa data menunjukkan penyebaran titik-titik data cenderung mendekati garis diagonal. Sehingga dapat disimpulkan bahwa data yang diolah merupakan data yang berdistribusi normal dan uji normalitas terpenuhi. 
Multikolinieritas digunakan untuk menguji apakah pada model regresi ditemukan adanya korelasi yang kuat antar variabel independen. Cara yang digunakan untuk menilainya adalah dengan melihat nilai faktor inflasi varians (Variance Inflasi Factor/VIF), yang tidak melebihi 4 atau 5 (Juliandi, Irfan, \& Manurung, 2014).

Tabel 1. Hasil Pengujian Multikolinearitas

\begin{tabular}{|c|c|c|c|}
\hline \multirow[b]{2}{*}{ Model } & & \multicolumn{2}{|c|}{ Collinearity Statistics } \\
\hline & & Tolerance & VIF \\
\hline \multirow[t]{4}{*}{1} & (Constant) & & \\
\hline & Kompensasi & ,667 & 1,500 \\
\hline & Lingkungan Kerja & ,681 & 1,469 \\
\hline & Motivasi & ,737 & 1,357 \\
\hline
\end{tabular}

Ketiga variabel independent yaitu $\mathrm{X}_{1}, \mathrm{X}_{2}$ dan $\mathrm{X}_{3}$ memiliki nilai VIF dalam batas toleransi yang telah ditentukan tidak melebihi 4 atau 5 sehingga tidak terjadi multikolonieritas dalam variabel independen penelitian ini.

Pengujian ini memiliki tujuan untuk mengetahui apakah dalm model regresi terjadi ketidaksamaan varian dari residual suatu pengamatan ke pengamatan lainnya. Jika varian dari residual satu pengamatan ke pengamatan lain tetap, maka disebut homokedassitas dapat diketahui dengan melalui grafik scatterplot antar nilai prediksi varabel independen dengan nilai residualnya

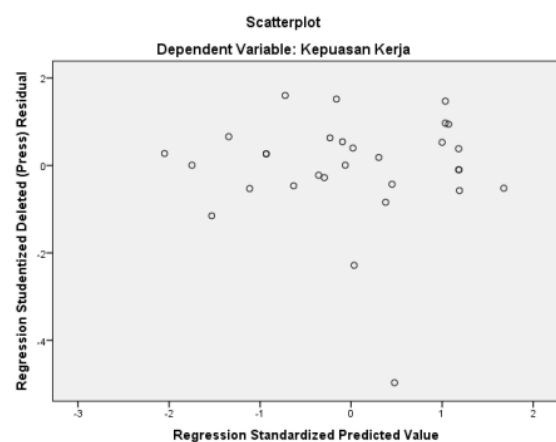

\section{Gambar 3. Hasil Pengujian Heteroskedasitas}

Dari gambar grafik scatterplot diatas dapat diketahui bahwa tidak terjadi heteroskedastisitas pada model regresi ini. Sebab tidak ada pola yang jelas serta titik-titik menyebar diatas dan dibawah angka 0 pada sumbu Y, maka kesimpulannya tidak terjadi heteroskedasitas.

\section{Regresi Linier Berganda}

Analisis regresi disusun untuk melihat hubungan yang terbangun antara variabel penelitian, apakah hubungan yang terbangun positif atau hubungan negative. Berdasarkan olahan data yang telah dilakukan, maka dapat diketahui bahwa model hubungan dari analisis regresi linier berganda dapat dilihat dari tabel berikut ini :

\section{Tabel 2. Regresi Linier Berganda}

\begin{tabular}{|c|c|c|c|c|c|c|}
\hline \multirow{2}{*}{\multicolumn{2}{|c|}{ Model }} & \multicolumn{2}{|c|}{$\begin{array}{l}\text { Unstandardized } \\
\text { Coefficients }\end{array}$} & \multirow{2}{*}{$\begin{array}{c}\begin{array}{c}\text { Standardized } \\
\text { Coefficients }\end{array} \\
\text { Beta } \\
\end{array}$} & \multirow[b]{2}{*}{$\mathrm{t}$} & \multirow[b]{2}{*}{ Sig. } \\
\hline & & B & Std. Error & & & \\
\hline \multirow[t]{4}{*}{1} & (Constant) & 12,074 & 7,565 & & 1,596 & ,123 \\
\hline & Kompensasi & ,323 &, 149 & ,397 & 2,170 &, 039 \\
\hline & Lingkungan Kerja & ,047 &, 161 & ,053 & ,294 & ,771 \\
\hline & Motivasi & ,434 &, 191 & ,396 & 2,276 & ,031 \\
\hline
\end{tabular}


Berdasarkan pada tabel 2 maka dapat disusun model penelitian persamaan regresinya adalah sebagai berikut :

$\mathrm{Y}=12,074+0,323 \mathrm{X}_{1}+0,047 \mathrm{X}_{2}+0,434 \mathrm{X}_{3}$

Model persamaan regresi berganda tersebut bermakna :

a. Nilai Konstanta sebesar 12,074 yang berarti bahwa jika variabel independen yaitu kompensasi $\left(\mathrm{X}_{1}\right)$, lingkungan kerja $\left(\mathrm{X}_{2}\right)$ dan motivasi $\left(\mathrm{X}_{3}\right)$ sama dengan nol, maka kepuasan kerja guru (Y) adalah sebesar 12,074.

b. Nilai koefisien regresi $\mathrm{X}_{1}=0,323$ menunjukkan apabila kompensasi mengalami kenaikan sebesar 100\% maka akan meningkatkan kepuasan kerja guru SMA Swasta Perkumpulan Amal Bakti 4 Sampali Medan sebesar 32,3\% kontribusi yang diberikan kompensasi terhadap kepuasan kerja guru dilihat dari standartdied coefficients pada tabel 2 diatas.

c. Nilai koefisien regresi $\mathrm{X}_{2}=0,047$ menunjukkan apabila lingkungan kerja mengalami kenaikan sebesar $100 \%$ maka akan mengakibatkan meningkatnya kepuasan kerja guru SMA Swasta Perkumpulan Amal Bakti 4 Sampali Medan sebesar 4,7\% kontribusi yang diberikan lingkungan kerja terhadap kepuasan kerja guru dilihat dari standartdied coefficients pada tabel 2 diatas.

d. Nilai koefisien regresi $\mathrm{X}_{3}=0,434$ menunjukkan apabila motivasi mengalami kenaikan sebesar 100\% maka akan mengakibatkan meningkatnya kepuasan kerja guru SMA Swasta Perkumpulan Amal Bakti 4 Sampali Medan sebesar 43,4\% kontribusi yang diberikan motivasi terhadap kepuasan kerja guru dilihat dari standartdied coefficients pada tabel 2 diatas.

\section{Pengujian Hipotesis}

\section{Uji t (Secara Parsial)}

Tujuan dari Uji t adalah untuk melihat apakah ada hubungan yang signifikan atau tidak dalam hubungan antara variabel $\mathrm{X}_{1}, \mathrm{X}_{2}$ dan $\mathrm{X}_{3}$ terhadap $\mathrm{Y}$.

\section{Tabel 3. Hasil Uji t}

\begin{tabular}{|c|c|c|c|c|c|c|}
\hline \multirow[b]{2}{*}{ Model } & & \multicolumn{2}{|c|}{$\begin{array}{l}\text { Unstandardized } \\
\text { Coefficients }\end{array}$} & \multirow{2}{*}{$\begin{array}{c}\text { Standardized } \\
\text { Coefficients } \\
\text { Beta }\end{array}$} & \multirow[b]{2}{*}{$\mathrm{t}$} & \multirow[b]{2}{*}{ Sig. } \\
\hline & & $\mathrm{B}$ & Std. Error & & & \\
\hline 1 & (Constant) & 12,074 & 7,565 & & 1,596 &, 123 \\
\hline & Kompensasi & ,323 &, 149 & ,397 & 2,170 &, 039 \\
\hline & Lingkungan Kerja & ,047 & , 161 & ,053 & ,294 & ,771 \\
\hline & Motivasi &, 434 & 191 & ,396 & 2,276 &, 031 \\
\hline
\end{tabular}

\section{Pengaruh Kompensasi Terhadap Kepuasan Kerja}

Hasil pengujian diperoleh nilai $t$ untuk variabel kompensasi menunjukkan nilai $t_{\text {hitung }}=2.170$ $>t_{\text {tabel }}=2.055$ dengan nilai signifikansi sebesar $=0,039<0.05$ dengan demikian berarti kompensasi memiliki pengaruh yang signifikan terhadap kepuasan kerja yang berarti Hipotesis diterima.

\section{Pengaruh Lingkungan Kerja Terhadap Kepuasan Kerja}

Hasil pengujian diperoleh nilai t untuk variabel lingkungan kerja menunjukkan nilai $t_{\text {hitung }}=0.294<t_{\text {tabel }}=2.055$ dengan nilai signifikansi sebesar $=0,771>0,05$ yang berarti menunujukkan bahwa lingkungan kerja tidak memiliki pengaruh yang signifikan terhadap kepuasan kerja hal ini berarti Hipotesis ditolak.

\section{Pengaruh Motivasi terhadap Kepuasan Kerja}

Hasil pengujian diperoleh nilai $\mathrm{t}$ untuk variabel Motivasi menunjukkan nilai $\mathrm{t}_{\text {hitung }}=$ $2.276>\mathrm{t}_{\text {tabel }}=2.055$ dengan nilai signifikansi sebesar $=0,031<0,05$ yang berarti 
menunujukkan bahwa motivasi memiliki pengaruh yang signifikan terhadap kepuasan kerja hal ini berarti Hipotesis diterima.

\section{Uji F (Secara Simultan)}

Uji statistik F (simultan) dilakukan untuk mengetahui apakah variabel bebas (independent) secara bersama-sama berpengaruh secara signifikan atau tidak terhadap variabel terikat (dependen). Hasil uji secara simultan dapat dilihat dari tabel dibawah ini :

Tabel 4. Hasil Uji F

\begin{tabular}{|c|c|c|c|c|c|c|}
\hline \multicolumn{2}{|c|}{ Model } & Sum of Squares & $\mathrm{df}$ & Mean Square & $\mathrm{F}$ & Sig. \\
\hline \multirow[t]{3}{*}{1} & Regression & 91,885 & 3 & 30,628 & 6,280 &, $002^{b}$ \\
\hline & Residual & 126,815 & 26 & 4,877 & & \\
\hline & Total & 218,700 & 29 & & & \\
\hline
\end{tabular}

a. Dependent Variable: Kepuasan Kerja

b. Predictors: (Constant), Motivasi, Lingkungan Kerja, Kompensasi

Dari hasil pengolahan data di atas terlihat bahwa nilai $\mathrm{F}_{\text {hitung }}=6.280>$ dari $\mathrm{F}_{\text {tabel }}=4.23$ (lihat tabel $\mathrm{F}$ untuk $\mathrm{N}=26$ ) dengan nilai probabilitas yakni sig adalah sebesar 0,002<0,05. Artinya kompensasi, lingkungan kerja dan motivasi secara simultan berpengaruh signifikan terhadap kepuasan kerja, maka keputusannya Hipotesis diterima.

\section{Koefisien Determinasi $\left(\mathbf{R}^{2}\right)$}

Koefisien determinasi ini digunakan untuk mengetahui seberapa besar pengaruh variabel-variabel bebas memiliki pengaruh terhadap variabel terikatnya. Nilai koefisien determinasi ditentukan dengan nilai $R$ square.

Tabel 5. Koefisien Determinasi

\begin{tabular}{lcccc}
\hline Model & $\mathrm{R}$ & $\mathrm{R}$ Square & $\begin{array}{c}\text { Adjusted } \mathrm{R} \\
\text { Square }\end{array}$ & $\begin{array}{c}\text { Std. Error of the } \\
\text { Estimate }\end{array}$ \\
\hline 1 &, $648^{\mathrm{a}}$ &, 420 &, 353 & 2,20850 \\
\hline a. Predictors: (Constant), Motivasi, Lingkungan Kerja, Kompensasi & \\
\hline \multicolumn{2}{l}{ b. Dependent Variable: Kepuasan Kerja } & & & \\
\hline
\end{tabular}

Dari hasil pengolahan data di atas terlihat bahwa nilai koefisien korelasi (R Square) sebesar 0,420, hal ini berarti kompensasi, lingkungan kerja dan Motivasi secara bersama-sama berpengaruh sebesar $42 \%$ sedangkan sisanya $58 \%$ kepuasan kerja dipengaruhi oleh variabel lain yang tidak ada dalam penelitian ini.

\section{PEMBAHASAN}

\section{Pengaruh Kompensasi terhadap Kepuasan Kerja}

Berdasarkan hasil penelitian mengenai pengaruh antara kompensasi terhadap kepuasan kerja guru pada SMA Swasta Perkumpulan Amal Bakti 4 Sampali Medan yang menyatakan thitung $\geq$ ttabel yaitu $2.170 \geq 2.055$ berada di daerah penerimaan Ha sehingga $\mathrm{H} 0$ ditolak, hal ini dinyatakan bahwa kompensasi berpengaruh signifikan secara parsial terhadap kepuasan kerja guru di SMA Swasta Perkumpulan Amal Bakti 4 Sampali Medan. Artinya tingkat kompensasi secara positif maupun negatif dapat mempengaruhi kepuasan kerja guru pada sekolah tersebut. Hasil penelitian ini menyatakan bahwa ada pengaruh antara kompensasi terhadap kepuasan kerja. Hal ini sejalan dengan hasil penelitian terdahulu (Jufrizen, Gultom, Sitorus, Sari, \& Nasution, 2018); (Bancin, 2016); (Jufrizen, 2015); (Harahap \& Khair, 2019); (Azhar, Nurdin, \& Siswadi, 2020); (Jufrizen, Lumbanraja, Salim, \& Gultom, 2017); (Nasution, Prayogi, Jufrizen, Pulungan, \& Juliandi, 2019) yang menunjukkan bahwa kompensasi berpengaruh terhadap kepuasan kerja. 


\section{Pengaruh Lingkungan Kerja terhadap Kepuasan Kerja}

Berdasarkan hasil penelitian mengenai pengaruh antara lingkungan kerja terhadap kepuasan kerja guru pada SMA Swasta Perkumpulan Amal Bakti 4 Sampali Medan yang menyatakan thitung $\leq$ ttabel yaitu $0.771 \leq 2.055$ berada di daerah penerimaan $\mathrm{H} 0$ sehingga $\mathrm{Ha}$ ditolak, hal ini di nyatakan bahwa lingkungan kerja berpengaruh tidak signifikan secara parsial terhadap kepuasan kerja guru di SMA Swasta Perkumpulan Amal Bakti 4 Sampali Medan. Hasil penelitian ini menyatakan bahwa tidak terdapat pengaruh signifikan antara lingkungan kerja terhadap kepuasan kerja. Hal ini tidak sejalan dengan hasil penelitian terdahulu (Astuti \& Iverizkinawati, 2018); (Hasibuan, 2015); (Wibowo, Musadieq, \& Nurtjahjono, 2014) yang menunjukkan bahwa lingkungan kerja berpengaruh terhadap kepuasan kerja.

\section{Pengaruh Motivasi terhadap Kepuasan Kerja}

Berdasarkan hasil penelitian mengenai pengaruh antara motivasi terhadap kepuasan kerja pada SMA Swasta Perkumpulan Amal Bakti 4 Sampali Medan yang menyatakan thitung $\geq$ ttabel yaitu $2.276 \geq 2.055$ berada di daerah penerimaan Ha sehingga $\mathrm{H} 0$ ditolak, hal ini di nyatakan bahwa motivasi berpengaruh signifikan secara parsial terhadap kepuasan kerja guru di SMA Swasta Perkumpulan Amal Bakti 4 Sampali Medan. Hasil penelitian ini menyatakan bahwa ada pengaruh antara motivasi terhadap kepuasan kerja. Hal ini sejalan dengan hasil penelitian terdahulu (Siahaan et al., 2014); (Kartika \& Kaihatu, 2010); (Sudiarditha, Waspodo, \& Triami, 2016); (Dolphina, 2012) yang menunjukkan bahwa motivasi berpengaruh terhadap kepuasan kerja.

\section{Pengaruh Kompensasi, Lingkungan Kerja dan Motivasi terhadap Kepuasan Kerja}

Mengenai pengaruh antara kompensasi, lingkungan kerja dan motivasi terhadap kepuasan kerja guru di SMA Swasta Perkumpulan Amal Bakti 4 Sampali Medan pada penelitian ini sudah jelas terbukti ada pengaruh secara simultan, di mana hasil uji $\mathrm{F}$ di dapat nilai Fhitung $\geq$ Ftabel yaitu $6.280 \geq 4.23$ dengan signifikan $0,002<0,05$. Karena Fhitung lebih besar dari Ftabel maka H0 di tolak dan Ha di terima artinya ada pengaruh antara kompensasi, lingkungan kerja dan motivasi terhadap kepuasan kerja guru di SMA Swasta Perkumpulan Amal Bakti 4 Sampali Medan.

Hasil penelitian ini menyatakan bahwa ada pengaruh antara kompensasi, lingkungan kerja dan motivasi terhadap kepuasan kerja. Hal ini sejalan dengan hasil penelitian terdahulu (Husni et al., 2018) yang menunjukkan bahwa kompensasi, lingkungan kerja dan motivasi berpengaruh terhadap kepuasan kerja.

\section{KESIMPULAN}

Berdasarkan penelitian yang dilakukan pada SMA Swasta Perkumpulan Amal Bakti 4 Sampali Medan, maka dapat disimpulkan bahwa kompensasi secara parsial berpengaruh positif dan signifikan terhadap kepuasan kerja. Lingkungan kerja secara parsial berpengaruh positif dan tidak signifikan terhadap kepuasan kerja. Motivasi secara parsial berpengaruh positif dan signifikan terhadap kepuasan kerja. Kompensasi, lingkungan kerja dan motivasi secara simultan berpengaruh signifikan terhadap kepuasan kerja. Berdasarkan kesimpulan diatas, maka dalam hal ini penulis dapat menyarankan hal-hal yaitu : bagi pihak sekolah, sebaiknya memperhatikan kompensasi yang diberikan kepada guru yang disesuaikan dengan masa kerja atau beban kerja mereka berupa finansial atau pun non finansisal, baik langsung maupun tidak langsung. Adapun bentuk kompensasi financial adalah gaji, tunjangan, bonus, dan komisi. Sedangkan untuk kompensasi non-financial diantaranya pelatihan, wewenang dan tanggung jawab, penghargaan atas kinerja mereka. Lingkungan kerja juga dapat mempengaruhi kepuasan 
guru dalam bekerja, apabila lingkungan kerja mendukung maka akan menciptakan suasana kerja yang nyaman bagi para guru sehingga mampu meningkatkan kepuasan kerja yang lebih tinggi. Bagi pihak sekolah, sebaiknya lebih memperhatikan lingkungan kerja baik secara fisik seperti penerangan, pewarnaan, kebersihan, perputaran udara, keamanan dan kebisingan maupun non fisik seperti suasana kerja, hubungan antar sesama dan hubungan antar guru dengan pimpinan demi kenyamanan guru dalam bekerja guna menciptakan kepuasan kerja yang diharapkan mampu meningkatkan produktifitas kerja guru sehingga sekolah dapat mencapai tujuan sesuai dengan visi dan misi sekolah. Motivasi yang tinggi akan menghasilkan kepuasan bagi para guru apabila diberikan secara terus menerus, untuk itu diharapkan agar motivasi lebih diperhatikan lagi guna menjaga semangat kerja bagi para guru sehingga mereka puas dalam bekerja. Bagi pihak sekolah, dalam rangka meningkatkan kepuasan kerja guru maka yang perlu diperhatikan adalah meningkatkan motivasi kerja melalui pemberian penghargaan kepada guru yang dianggap berprestasi.

\section{DAFTAR PUSTAKA}

Agustini, F. (2011). Manajemen Sumber Daya Manusia Lanjutan. Medan: Madenatera.

Arianty, N., Bahagia, R., Lubis, A. A., \& Siswadi, Y. (2016). Manajemen Sumber Daya Manusia. Medan: Perdana Publishing.

Astuti, R., \& Iverizkinawati, I. (2018). Pengaruh Kepemimpinan dan Lingkungan Kerja terhadap Kepuasan Kerja Karyawan pada PT. Sarana Agro Nusantara Medan. Jurnal Ilmiah Manajemen, 6(1), 26-41.

Azhar, M. E., Nurdin, D. U., \& Siswadi, Y. (2020). Pengaruh Disiplin Kerja dan Kompensasi Terhadap Kepuasan Kerja Karyawan. Jurnal Humaniora: Jurnal Ilmu Sosial, Ekonomi Dan Hukum, 4(1), 46-60. https://doi.org/10.30601/humaniora.v4i1.422

Bancin, A. (2016). Pengaruh Kompensasi Non Finansial Dan Pengembangan Karir Terhadap Kepuasan Kerja Karyawan Pada PT. Jasa Marga (PERSERO) Cabang Belmera Medan. Jurnal Ilmiah Manajemen Bisnis, 17(2), 27-40.

Bangun, W. (2018). Manajemen Sumber Daya Manusia. Jakarta: Erlangga.

Bismala, L., Arianty, N., \& Farida, T. (2017). Perilaku Organisasi. Medan: Lembaga Penelitian dan Penilisan Ilmiah Aqli.

Daulay, R., Khair, H., Putri, L. P., \& Astuti, R. (2017). Manajemen. Medan: Lembaga penelitian dan Penulisan Ilmiah AQLI.

Dolphina, E. (2012). Pengaruh Motivasi, Kepemimpinan dan Budaya Kerja terhadap Kepuasan Kerja Karyawan serta Dampaknya pada Kinerja Perusahaan. Semantik, 2(1), 1-7.

Gijoh, R. (2013). Motivasi, Kompetensi Dan Budaya Kerja Pengaruhnya Terhadap Kepuasan Kerja Karyawan Outsourcing Pada Hotel Sintesa Peninsula Manado. Jurnal EMBA: Jurnal Riset Ekonomi, Manajemen, Bisnis Dan Akuntansi, 1(4), 1963-1973. https://doi.org/10.35794/emba.v1i4.3404

Hamali, A. Y. (2016). Manajemen Sumber Daya Manusia (1st ed.). Yogyakarta: Media Pressindo Group.

Handoko. (2013). Manajemen Personalia dan Sumber Daya Manusia. Yogyakarta: BPEE.

Handoko, D. S., \& Rambe, M. F. (2018). Pengaruh Pengembangan Karir dan Kompensasi Terhadap Komitmen Organisasi Melalui Kepuasan Kerja. Maneggio: Jurnal Ilmiah Magister Manajemen, $1(1)$

$31-45$. https://doi.org/http://doi.org/10.30596/maneggiov,v1i1.2238

Handoko, T. H. (2011). Manajemen Personalia dan Sumber Daya Manusia. Yogyakarta: BPFE.

Harahap, D. S., \& Khair, H. (2019). Pengaruh Kepemimpinan Dan Kompensasi Terhadap 
Kepuasan Kerja Melalui Motivasi Kerja. Maneggio: Jurnal Ilmiah Magister Manajemen, 2(1), 69-88. https://doi.org/10.30596/maneggio.v2i1.3404

Hasibuan, J. S. (2015). Pengaruh Lingkungan Kerja Dan Budaya Organisasi Terhadap Kepuasan Kerja Karyawan Pada PT. Sarana Agro Nusantara Medan. Kumpulan Jurnal Dosen Unversitas Muhammadiyah Sumatera Utara, 3(2).

Hasibuan, M. S. P. (2018). Manajemen Sumber Daya Manusia. (Lia Malyani, Ed.). Bandung: Yrama Widya.

Hidayati, S. N., \& Saputra, S. D. (2018). Pengaruh Kepemimpinan, Kompensasi, Komunikasi, dan Motivasi Kerja terhadap Turnover Intention Pegawai dengan Kepuasan Kerja sebagai "Variabel Antara." Jurnal Maksipreneur, 7(2), 162-1173. https://doi.org/10.30588/jmp.v7i2.365

Husni, H., Musnadi, S., \& Faisal, F. (2018). Pengaruh Lingkungan Kerja, Kompensasi Dan Motivasi Terhadap Kepuasan Kerja Serta Dampaknya Terhadap Loyalitas Kerja Pegawai Rutan Di Provinsi Aceh (Studi Kasus Pada Rutan Klas II B Banda Aceh Dan Rutan Klas II B Jantho). Jurnal Magister Manajemen, 2(1), 88-98.

Jufrizen, J. (2015). Pengaruh Kompensasi Dan Pengembangan Karir Terhadap Komitmen Organisasi Dengan Kepuasan Kerja Sebagai Variabel Intervening Pada PT. Perkebunan Nusantara III (Persero) Medan. Jurnal Ilmiah Manejemen Dan Bisnis, 15(1), 37-47. https://doi.org/10.30596/jimb.v15i1.965

Jufrizen, J. (2016). Efek Mediasi Kepuasan Kerja Pada Pengaruh Kompensasi Terhadap Kinerja Karyawan. Jurnal Ilmiah Manajemen Dan Bisnis, 17(1). https://doi.org/10.30596/jimb.v17i1.1209

Jufrizen, J., Gultom, D. K., Sitorus, S. A., Sari, M., \& Nasution, M. I. (2018). The Effect of Organizational Culture and Islamic Work Ethic on Permanent Lecturers' Job Satisfaction, Organizational Commitment And Work Performance at Private Islamic Universities in the City of Medan. In Proceeding 1st International Conference of Economic Studies (ICOES) 2018 (pp. 179-186).

Jufrizen, J., Lumbanraja, P., Salim, S. R. A., \& Gultom, P. (2017). The Effect of Compensation, Organizational Culture and Islamic Work Ethic Towards the Job Satisfaction and the Impact on the Permanent Lecturers. International Business Management, 11(1), 53-60.

Juliandi, A., Irfan, I., \& Manurung, S. (2014). Metodologi Penelitian Bisnis, Konsep dan Aplikasi: Sukses Menulis Skripsi \& Tesis Mandiri. Medan: UMSU Press.

Kartika, E. W., \& Kaihatu, T. S. (2010). Analisis Pengaruh Motivasi Kerja Terhadap Kepuasan Kerja (Studi Kasus Pada Karyawan Restoran Di Pakuwon Food Festival Surabaya). Jurnal Manajemen Dan Kewirausahaan, 12(1), 100-112. https://doi.org/10.9744/jmk.12.1.pp.\%20100-112

Khair, H. (2017). Manajemen Kompensasi. Medan: Madenatera.

Khair, H., Bismala, L., Arianty, N., \& Pratami, L. (2016). Manajemen Strategi. (S. Manurung, Ed.) (1st ed.). Medan: UMSU PRESS.

Mahendrawan, I. G., \& Indrawati, A. D. (2015). Pengaruh Beban Kerja Dan Kompensasi Terhadap Kepuasan Kerja PT Panca Dewata Denpasar. E-Jurnal Manajemen Unud, 4(11), 3936-3961.

Mangkunegara, A. A. A. P. (2014). Evaluasi Kinerja Sumber Daya Manusia. Bandung: Refika Aditama.

Mangkunegara, A. A. A. P. (2016). Manajemen Sumber Daya Manusia Perusahaan. Bandung: PT. Remaja Rosdakarya.

Mangkunegara, A. A. A. P. (2017). Manajemen Sumber Daya Manusia Perusahaan. Bandung: PT Remadja Rosdakarya. 
Manullang, M. (2012). Dasar-Dasar Manajemen. Yogyakarta: Gadjah Mada University Press. Nabawi, R. (2019). Pengaruh Lingkungan Kerja, Kepuasan Kerja dan Beban Kerja Terhadap Kinerja Pegawai. Meneggio : Jurnal Ilmiah Magister Manajemen, 2(2), 170-183.

Nasution, M. I., Prayogi, M. A., Jufrizen, J., Pulungan, D. R., \& Juliandi, A. (2019). Compensation and Organizational Commitment: The Mediating Role of Job Satisfaction. In Proceedings of The 2nd International Conference On Advance And Scientific Innovation, ICASI 2019 (pp. 1-10). https://doi.org/10.4108/eai.18-7-2019.2288578

Nitisemito, A. S. (2011). Manajemen Personalia (Manajemen Sumber Daya Manusia) (Kelima). Ghalia.

Panggabean, M. (2004). Manajemen Sumber Daya Manusia (Edisi 2). Bogor: Ghalia Indonesia.

Parmin, P. (2017). Pengaruh Kompensasi, Kompetensi Dan Motivasi Kerja Terhadap Kinerja Guru Tidak Tetap (GTT) Dengan Kepuasan Kerja Sebagai Variabel Intervening. Jurnal Fokus Bisnis, 16(1), 21-39. https://doi.org/10.32639/fokusbisnis.v16i01.78

Robbins, S. P. (2012). Perilaku Organisasi. Jakarta: Salemba Empat, Jakarta.

Sedarmayanti, S. (2017). Manajemen Sumber Daya Manusia. Bandung: Refika Aditama.

Siahaan, B. N., Salim, S. R. A., \& Siahaan, E. (2014). Pengaruh Kepemimpinan dan Motivasi Kerja Terhadap Kinerja Karyawan Melalui Kepuasan Kerja Karyawan Akademi Manajemen Informatika komputer Medan Business Polytechnic Medan (AMIK MBP) Medan. Jurnal Manajemen Sains, 2(4), 437-481.

Soetjipto, B. W. (2010). Manajemen Sumberdaya Manusia Sebuah Tinjauan Komprehensif. Jakarta: Amara Books.

Sudiarditha, I. K. R., Waspodo, A. A., \& Triami, N. A. (2016). Pengaruh Lingkungan Kerja Dan Motivasi Kerja Terhadap Kepuasan Kerja Karyawan Pada Direktorat Umum Lembaga Pelayanan Publik Televisi Republik Indonesia. Jurnal Manajemen, 20(02), 278292.

Sugiyono. (2017). Metode Penelitian Kuantitatif dan $R \& D$ (Ketiga). Bandung: Alfabeta.

Sutrisno, E. (2014). Mnajemen Sumber Daya Manusia. Kencana Prenada Media Group.

Tamali, H., \& Munasip, A. (2019). Pengaruh Kompensasi, Kepemimpinan, Dan Lingkungan Kerja Terhadap Kepuasan Kerja Karyawan. Maneggio: Jurnal Ilmiah Magister Manajemen, 2(1), 55-68. https://doi.org/10.30596/maneggio.v2i1.3403

Wibowo, M., Musadieq, M. Al, \& Nurtjahjono, G. E. (2014). Pengaruh Lingkungan Kerja Terhadap Kepuasan Kerja Karyawan. Jurnal Administrasi Bisnis, 16(1), 1-9.

Wibowo, W. (2015). Perilaku Dalam Organisasi. Jakarta: Pt. RajaGrafindo Persada. 